\title{
Limites e intersecções do estético com o político no filme Janela indiscreta, de Alfred Hitchcock, e no conto "Sessão das quatro", de Roberto Drummond \\ Wanderlan da Silva Alves ${ }^{1}$
}

\author{
Necessitas legem non habet ${ }^{2}$ \\ (máxima latina) \\ A tarefa de uma crítica da \\ violência (do poder) pode ser \\ definida como a apresentação \\ de suas relações com o \\ direito e com a justiça. \\ Walter Benjamin
}

A linguagem cinematográfica, por sua condição híbrida, haja vista que se constitui por meio de imagens, de sons articulados, de ruídos e de sons puros e, enfim, do próprio movimento dinâmico que os põe em relação no processo de significação que a legitima como sendo uma linguagem, se justifica como possibilidade de ampliação da percepção humana. Nisso, a fotografia e o cinema se aproximam bastante. "Tudo se passa como se as convenções (as duas dimensões, o preto e branco, o enquadramento, as diferenças de escala entre os planos) contribuíssem para nos libertar de nossas próprias convenções" (Robbe-Grillet, 1963, p. 23). Ou, ainda, para reafirmá-las para o espectador, num processo em que a linguagem refere o mundo, representando-o, mas refere-se, especialmente, a si mesma, à sua própria forma e a seu modo de significar.

Por outro lado, "o aspecto um pouco fora do habitual deste mundo reproduzido revela-nos, ao mesmo tempo, o caráter inabitual do mundo que nos rodeia: ainda inabitual na medida em que recusa rejeitar-se aos nossos hábitos de percepção e à nossa ordem" (id., ibid., grifo do autor). Tal estranhamento pode colaborar para a apreensão dos modos como a significação de tais hábitos e da referida ordem do cotidiano são engendrados e sustentados em nossa sociedade, revelando, talvez, suas próprias bases constitutivas, isto é, os elementos linguístico-discursivos que viabilizam

\footnotetext{
${ }^{1}$ Professor da Universidade Estadual da Paraíba (UFPB), Monteiro, Brasil. Doutorando em Letras (Teoria da Literatura) pela Universidade Estadual Paulista (Unesp), São José do Rio Preto, Brasil. Bolsista do CNPq. E-mail: alveswanderlan@yahoo.com.br

2 “A necessidade não tem lei."
} 
ou representam as práticas sociais e colocam em relação os indivíduos de uma determinada sociedade, numa dada época.

Na narrativa brasileira dos anos 1970-80, por vezes, textos e obras literárias estabelecem uma aproximação aos procedimentos da linguagem cinematográfica, tanto por meio de diálogos intertextuais ou atualizações temáticas quanto por meio da incorporação de procedimentos construtivos afins a ambas as linguagens, como se pode observar nas obras de autores como Caio Fernando Abreu, Ricardo Ramos, Roberto Drummond, entre outros. Talvez isso se deva ao fato de que, se comparada às demais linguagens, o cinema, enquanto linguagem, se instaura num lugar e numa condição excepcionais, uma vez que sua materialidade não opõe denotação e conotação e, desse modo, o que ela comunica, antes de mais, é a sua própria medialidade, ou seja, sua capacidade de mediar significados (denotativos) e significados (conotativos). Isto é, manifesta-se, sempre, como linguagem em execução, que é referente (ao mundo) e autorreferente. Essa é a problemática que nos interessa neste estudo, que se propõe analisar as aproximações temático-formais entre o filme Janela indiscreta (Rear Window) (1954), de Alfred Hitchcock, e o conto "Sessão das quatro" (1982), do escritor mineiro Roberto Drummond.

Nas duas narrativas, uma situação dramática aparentemente despretensiosa - no filme, um fotógrafo que observa, de sua janela, a vida cotidiana de seus vizinhos, acaba por desvendar um crime; no conto, uma senhora, de sua janela, testemunha o assassinato de um homem por quatro militares armados - coloca em questão o caráter vigiado das sociedades em que estão inseridos os indivíduos, no século XX, e as implicações jurídicas que essa permanente vigilância implica, na medida em que determinados códigos (éticos e morais) de comportamento ultrapassam as esferas da lei e passam a se confundir inteiramente com a vida, no universo ocupado pelas personagens de cada uma das narrativas. A problemática central de ambas as narrativas se estabelece, de modo amplo, nos limites entre o público e o privado e nos leva ao questionamento fundamental que norteia este estudo: como Janela indiscreta e "Sessão das quatro" assumem, em sua linguagem, a condição de discurso e forma que se produzem sob (e sobre) contexto de exceção? Em busca de formular algumas considerações a tal respeito, vamos nos deter, especialmente, em algumas situações dramáticas e em procedimentos construtivos de cada uma das narrativas mencionadas (primeira parte do estudo) e, posteriormente, na posição de enunciação ocupada pelo protagonista de cada texto (segunda parte do estudo), que está relacionada, de certo modo, à instância da narração e à noção de autoridade do narrador do relato (terceira parte do estudo). 


\section{Estados de atenção: dois crimes sob olhares vigilantes}

Lançado em 1954, o filme de Hitchcock, que se pode classificar como sendo um filme de suspense, narra um momento na vida de L. B. Jeffries (Jeff), um fotógrafo aventureiro que, por ter fraturado a perna esquerda, se vê obrigado a permanecer em seu apartamento, em Greenwich Village, Nova York, por alguns dias, em repouso. Ao longo desses dias, ocupa seu tempo em conversas com a enfermeira que vai atendê-lo diariamente (Stella), em momentos junto com a namorada Lisa, ou observando, pela janela, o dia a dia de seus vizinhos, numa espécie de vila formada por apartamentos contíguos. Sentado de frente para a sua janela, Jeff consegue acompanhar a vida dos outros moradores que vivem no mesmo lugar, vendo-os, dentro de suas casas ou nos espaços ao seu redor. Para escapar ao tédio, nos momentos em que está só em seu apartamento, a personagem fica observando os vizinhos com a ajuda de suas lentes-objetivas. $\mathrm{O}$ conjunto da vizinhança forma pequenos núcleos que são focalizados várias vezes no filme, o que constitui, também, um elemento rítmico da narrativa. Os principais núcleos observados por ele são: a bela bailarina que faz seus ensaios de dança em casa quando está sozinha e fica, em geral, seminua; o casal formado pelo o vendedor Thoward e sua esposa doente, que será vítima de assassinato pelo marido, situação em torno da qual se desenvolve toda a história narrada; o casal jovem sempre flagrado em cenas que sugerem o desencadeamento de relações amorosas; a "Coração solitário"; e a vizinha que vive com o marido, no apartamento imediatamente abaixo dos Thoward, a qual aparece geralmente em espaço aberto, tomando sol ou esculpindo em barro.

Enquanto tais personagens e suas ações são observadas por Jeff, a perspectiva do narrador se identifica com o próprio Jeff, e, como espectadores, vemos os acontecimentos que são observados por ele flagrados por uma câmera identificada com seus olhos. A multiplicidade de núcleos dramáticos, contudo, impõe à narrativa a necessidade de uma mobilidade do narrador, que faz a função-narrador do relato desprender-se, por vezes, da perspectiva exclusiva de uma única personagem, no caso, Jeff. Tal mobilidade sustenta o efeito simultâneo de suspense e de curiosidade resultantes, que estão associados ao comportamento da personagem-protagonista. Jeff apresenta, ainda, traços lúdicos identificados, em geral, à percepção de situações dramáticas dotadas de algum matiz erótico, o que se coaduna à função de protagonista galã, sustentada, no filme, por traços físicos masculinos e, também, pelo apego às 
ideias de liberdade e de aventura ${ }^{3}$. Nesse sentido, a câmera-olho, sob a perspectiva de Jeff, identificada com uma "visão com" (Pouillon, 1974), exerce uma função de desvendamento junto ao espectador, já que é a curiosidade da personagem que a guia, e tanto ela quanto o espectador só sabem aquilo que podem ver, no momento mesmo em que veem o que está sendo observado, no plano da enunciação. Por vezes, no entanto, essa visão assume um matiz testemunhal, uma vez que serve de registro documental dos acontecimentos que se desencadeiam na vila. Há, ainda, na narrativa, a focalização da personagem Jeff e de seu núcleo. Nos momentos em que isso ocorre, dá-se uma mudança na perspectiva do narrador, porém não identificada com o olhar da personagem, identificada, pois, com a "visão por detrás" (id.), quando mostra o apartamento do protagonista ou o protagonista e seu apartamento. Por fim, há, também, uma visão externa, que poderia ser caracterizada como heterodiegética (Aguiar e Silva, 1991), na medida em que ela alcança uma abrangência que tanto se mostra capaz de flagrar os acontecimentos narrados e as personagens envolvidas neles quanto se mostra dotada de uma mobilidade que não se restringe a um eixo fixo de observação.

De certo modo, o filme em questão assume a importância da distância estética entre leitor/espectador e narrador, entendendo que essa distância era fixa na narrativa tradicional, mas, agora, "ela varia como as posições da câmera do cinema: o leitor é ora deixado do lado de fora, ora guiado pelo comentário até o palco, os bastidores e a casa de máquinas" (Adorno, 2003, p. 61). Essa estratégia narrativa garante ao filme a manutenção do suspense, quando a focalização está identificada com os limites da câmera-olho (Jeff), sem privilegiar o protagonista colocando-o numa posição defensiva, pois, tendo em vista que ele também é flagrado, ele é visto em suas fraquezas e trivialidades do cotidiano, do mesmo modo que os vizinhos que ele observa.

Há, nisso, também, um matiz crítico do filme, pois, se a personagem

\footnotetext{
${ }^{3}$ A oposição de papéis se torna evidente, no filme, quando observamos que Lisa, sua namorada, cumpre a função de mocinha, a moça rica, bela e, aparentemente, incondizente com a realidade do amado (um fotógrafo, homem pobre que, em sua profissão, viaja pelo mundo, enfrentando os riscos do espaço selvagem, das intempéries naturais e dos escândalos públicos). Há que notar que, no desfecho na narrativa, no entanto, percebemos que Lisa, ao arriscar-se para desvendar o mistério acerca do desaparecimento da senhora Thoward, se mostra tão aventureira quanto ele e mostra-se capaz de corresponder às características necessárias, segundo a perspectiva de Jeff, para ser sua esposa. Há nisso, de certo modo, marcas da heroína romântica que se doa em nome de suas causas e de seu amor. O comportamento de Lisa, contudo, é ambivalente, sugerindo-nos, ironicamente, que ela não abandonou totalmente sua vida de moça rica, como vemos na última cena do filme, em que ela está, ao mesmo tempo, lendo um livro de aventuras e uma revista feminina. Na última cena do filme, Lisa lê enquanto Jeff está adormecido. A personagem troca a leitura aventureira pela outra, sugerindo-nos a permanência de ambos os traços em sua personalidade.
} 
protagonista ocupa um lugar privilegiado em relação às demais, por outro lado, ela se torna, também, objeto observado sob o olhar exterior, num permanente movimento de vigilância, em que os momentos individuais de intimidade estão, sempre, sob o olhar investigador e curioso de outrem. Tal mise-en-abîme já aponta para a condição do indivíduo representado na narrativa, inserido numa sociedade vigiada, na qual pode e parece haver, sempre, alguém deliberada ou casualmente posicionado de modo tal que possa observar todos os seus movimentos e, logo, operar, simbolicamente, de modo violento, na medida em que ver o outro se torna não um meio de aproximação e projeção de dramas e questões subjetivas individuais, mas, sim, uma infração à liberdade do indivíduo.

No filme, o procedimento da mise-en-abîme é empregado para colocar em questão os limites do público e do privado, bem como as implicações decorrentes da transgressão de tais limites. De certo modo, ao longo da história narrada vão se colocando certas questões éticas ou morais implicadas na espionagem de Jeff, durante os dias em que permanece em casa, com a perna fraturada. Seu olhar de desvendamento oscila entre a mera curiosidade, a curiosidade relacionada ao erotismo e a espionagem. Tratase da oposição entre o olhar descomprometido da personagem para passar o tempo, enquanto permanece em repouso, e a invasão da intimidade e da liberdade individuais de seus vizinhos em sua vida privada. Nesse sentido, o filme põe em discussão as questões éticas que a publicidade gerada pela câmera implica. Em Janela indiscreta, tal discussão é explícita e aparece já nas primeiras sequências de cena da narrativa fílmica. Stella, a enfermeira de Jeff, ao notar que ele passa seus dias olhando a vida dos vizinhos pela janela, reprova-o, dizendo-lhe:

Abelhudos, em Nova York, são condenados a seis meses. (...) Antigamente, furariam seus olhos com um ferro em brasa. Viramos uma raça de xeretas. As pessoas deveriam sair de casa e olhar para si mesmas. (...) (Depois ironizando-o, diz:) posso vê-lo no tribunal, cercado de advogados, diante do juiz, dizendo que era apenas diversão inocente ${ }^{4}$.

A personagem tanto reprova o ato de Jeff quanto problematiza a transformação da sociedade que integram, na qual os indivíduos se encontram, segundo ela, cada vez mais distantes uns dos outros, cada vez mais envolvidos por contatos mediados por representações e tecnologias (uma das quais é a imagem gerada pela câmera), porém distantes em suas relações intersubjetivas. No filme, essa situação é concreta: por um lado, Jeff vê

\footnotetext{
${ }^{4} \mathrm{O}$ trecho aparece entre 8 e 10,5 min. após o início da narrativa fílmica. Trecho citado a partir da legenda em português do filme em questão.
} 
todas as demais personagens - seus vizinhos - , acompanha suas ações ao longo do dia, suas angústias (a "Coração Solitário" com a solidão; os Thoward e seu casamento problemático, a beleza e a tristeza da música do compositor solitário) e suas vivências privadas (o erotismo do jovem casal, as investidas dos pretendentes da bailarina); por outro lado, não mantém nenhum contato direto com elas - as únicas vezes que se dirige a um de seus vizinhos são: a) por meio do bilhete anônimo ao senhor Thoward, como estratégia para tentar desvendar o crime; e b) a ligação anôni$\mathrm{ma}$, também, ao senhor Thoward, igualmente com fins investigativos. Isto é, os contatos são sempre mediados e portam funções pragmaticamente definidas.

Janela indiscreta capta com exatidão a complexidade do lugar do espectador, uma vez que este, enquanto instância necessária sem a qual o filme não completa seu percurso comunicativo, se coloca numa posição privilegiada e se torna, ao mesmo tempo, cúmplice dos acontecimentos do filme. Tal condição nos permite perceber a naturalidade com que o espectador contemporâneo assume a espetacularização como um procedimento por meio do qual o indivíduo vivencia um acontecimento, ao mesmo tempo, do mesmo lugar que o outro (identificado com ele) e de fora de tal lugar.

O desenvolvimento da vida dos indivíduos imersos nesse contexto de permanente vigilância - tal como se configura no filme em questão e, também, no conto de Roberto Drummond, como veremos - proporciona, entre outras, duas implicações distintas, ambas incômodas, se pensarmos nas narrativas em análise:

1) sob a perspectiva do observado: a) se o indivíduo percebe tal cerceamento, pode submeter-se a ele, ignorá-lo ou fingir ignorá-lo, deixandose ver5; b) se o indivíduo não percebe que é observado, corre o risco de tornar-se objeto de outro indivíduo;

\footnotetext{
${ }^{5}$ Essa questão é mais claramente posta no texto de Drummond, como veremos adiante, mas ela aparece, também, internamente, na narrativa de Janela indiscreta. Como passatempo para a personagem Jeff, assistir ao dia a dia de seus vizinhos constitui, também, um modo de coisificá-los, ao menos no microcosmo que o núcleo narrativo constituído por Jeff e os que têm acesso ao seu apartamento representa na narrativa. Os vizinhos são, num extremo, personagens que o divertem ou o intrigam. O Senhor Thoward, se visto do ponto de vista formal - desconsiderando-se, por um instante, os aspectos éticos que levam Jeff a investigá-lo, isto é, o desaparecimento da senhora Thoward -, é vítima da espionagem de Jeff. A estratégia de defesa do senhor Thoward se torna possível exatamente no momento em que ele toma consciência de que fora observado e que Jeff sabe que ele cometeu um crime, assassinando a própria esposa. Como estratégia formal, a saída encontrada por Thoward surge quando ele se descobre sendo observado. Lisa, depois de ter entrado no apartamento do investigado e de ter sido pega em flagrante pelo senhor Thoward, é socorrida pela polícia. Ao sinalizar a Jeff, discretamente pela janela, que tinha encontrado uma prova contra o suspeito, ela deixa Thoward perceber que era do apartamento de Jeff que ele estava sendo investigado. Thoward, então, se torna
} 
2) do ponto de vista do observador: a) a percepção crítica de que é um observador pode levar ao questionamento de seu ato de observar e das implicações éticas e morais disso; ou b) a assunção ambígua e indeterminada da posição de espectador, cujos riscos de alienação colaboram tanto para a reificação do observado quanto do próprio observador, pode, de modo ambivalente, constituir-se numa estratégia autodefensiva (como demonstraremos adiante).

Vejamos, então, o conto "Sessão das quatro", que é o décimo terceiro do livro Quando fui morto em Cuba, publicado pela primeira vez em 1982, e aparece na segunda parte do livro, intitulada " $2^{\circ}$ tempo", pois o livro está organizado, estruturalmente, como uma partida de futebol, com primeiro tempo, intervalo e segundo tempo. A fábula (Tomachevski, 2004) do conto é, basicamente, a seguinte: Geninha e Ciana são duas irmãs que vivem num sobrado de uma cidade (não nomeada, mas, por sugestão, uma cidade média dos anos 1960-70, no Brasil, provavelmente situada em Minas Gerais, talvez Belo Horizonte). Geninha é paralítica, está numa cama há vinte e nove anos, e Ciana se posiciona diariamente na janela e começa a olhar a praça da cidade, em geral interessada em observar os encontros amorosos de casais que acontecem nessa praça. Numa sexta-feira, ela vê militares conversando e loucos caminhando na praça, numa tarde aparentemente normal. Porém Ciana nota que está armada uma emboscada para um negro e acaba testemunhando todo o desenrolar de um assassinato cometido pelos militares, numa ação cujo processo ela acompanha durante os quarenta minutos que fica observando a praça pela janela, das 15 h35 às 16 h15.

Segundo o narrador, "Todos os dias, à exceção dos domingos, ela ficava na janela vendo os casais que se beijavam dentro dos carros e nos bancos da praça" (Drummond, 1983, p. 116) e sempre contava tudo o que acontecia à irmã, há vinte e nove anos paralítica. E, por vezes, inventava coisas para distrair a irmã. De certo modo, ela transforma (para si) o que vê numa espécie de filme, em geral romântico, com o qual se distrai e passa o tempo projetando personalidades famosas nos indivíduos que vê. "Se a velha de óculos entrasse no Volks Azul (que ela perdeu de vista) ia notar que a mulher de minissaia nada tinha de Greta Garbo: mais exatamente, lembrava um animal selvagem, não domesticado, e tinha cabelos fulvos" (id., p. 117). Como nota o narrador, ela não só identifica a mulher

consciente dos acontecimentos. Por outro lado, no conto de Drummond, como veremos, a estratégia é distinta e consiste no escamoteamento ou na aparente inconsciência acerca dos acontecimentos por parte do observador, como alternativa ambivalente de enfrentamento das coerções políticas e autoritárias a que está exposto. 
que aparece lentamente na praça num Volks azul com a figura de Greta Garbo, apesar de o narrador afirmar que não havia qualquer semelhança entre ambas, mas ela passa, ainda, a referir-se à mulher como sendo a própria Greta Garbo, fato que põe em xeque a sua posição crítica diante dos fatos que vê. Tal procedimento implica, por um lado, a negação de sua realidade imediata, de modo que ela passa a ver os acontecimentos da praça como uma ficção, a sessão das quatro, mas, ao mesmo tempo, implica uma ficcionalização de sua própria vida - dela e dos demais envolvidos na trama - , na medida em que ela acaba por imaginar um filme do qual talvez faça parte, criando-o, de fato, para si. Como observa Guelfi, Os contos de Roberto Drummond tematizam o relacionamento entre realidade e fantasia, sonho e cotidiano, loucura e sanidade, individualismo e coletivismo, liberdade e prisão, cultura e barbárie, ficção e real. Os frágeis limites entre esses universos são questionados, demonstrando-se a interação profunda entre os diferentes níveis de realidade. (Guelfi, 2007, p. 123)

Em "Sessão das quatro", a complexidade da situação se deve ao fato de que se torna difusa a representação do controle ou da alienação da personagem em relação aos acontecimentos que presencia: "Quando, por qualquer razão (chuva, frio etc.), os casais desapareciam da praça, a velha de óculos inventava cenas eróticas e as contava para distrair a irmã" (Drummond, 1983, p. 116), relata o narrador, sugerindo que a personagem se diverte conscientemente ao ficcionalizar o cotidiano, reinventando-o para a irmã. Mas também observa: " - Está chovendo, Ciana? - pergunta a velha paralítica.// - Só uns pingos, Geninha, mas se Santa Bárbara não ajudar, adeus Sessão das Quatro - disse a velha de óculos." (id., p. 122) E, aqui, seu envolvimento com a situação é tamanho que, para ela, já não importa o que está acontecendo, pois o acontecimento, sob a ótica de um filme, ganha autenticidade porque corresponde a um registro automático (...). Como resultado do encontro do olhar e do sistema de lentes (a objetiva da câmera) e o "acontecimento", fica depositada uma imagem deste que funciona como um documento. (Mas) Quando se esquece a função do recorte, prevalecendo a fé na evidência da imagem isolada, temos um sujeito totalmente cativo ao processo de simulação por mais simples que ele pareça". (Xavier, 1988, p. 368, grifo nosso)

Cativa (a personagem)? O espetáculo, no conto, parece se sobrepor ao drama humano que a emboscada expõe a todos (o cerceamento à liberdade individual) e à ameaça que está se desenhando contra o negro. A velha de óculos parece não se chocar com a crueldade nem com a violência do 
acontecimento que está se desenvolvendo diante dela, apenas se preocupa com a eficácia e a realização do que ela está acompanhando como se fosse um filme de faroeste ao vivo. Em momento algum ela põe em questão o porquê da perseguição ao negro nem procura fazer qualquer coisa para evitar que ele seja assassinado. Acompanha o desenvolvimento da ação, com o olhar fixo em seus dois principais núcleos - o núcleo amoroso, entre a mulher do Volks azul e o homem alourado do Volks areia - e o núcleo de perseguição ao negro, constituído pelo negro que se aproxima e pela perua parada embaixo da árvore na praça, levando quatro militares. Ciana percebe que um crime vai acontecer, mas, aparentemente, se envolve com ele apenas como espectadora de um filme. Ao longo de todo o conto, cuja ação central só se desenvolve, de fato, nos três últimos fragmentos, Ciana alimenta para si, e cria para Geninha, um efeito de suspense sobre o que conta, despertando, desse modo, o interesse de sua interlocutora e, também do leitor, fazendo-o de modo ambivalente, uma vez que se preocupa com o andamento das ações, mas não parece envolver-se com a natureza deles (trata-se de um assassinato real, aparentemente premeditado, acontecendo na frente da sua casa). A sugestão de que se trata de algo comum em seu cotidiano torna a situação mais dramática e indefinida, pois a vagueza com que Ciana se refere a tais acontecimentos os torna, potencialmente, referentes ao crime contra o negro e ao encontro de casais na praça. No plano da história narrada, o suspense procura se sobrepor à violência do acontecimento, o que sustenta o efeito de tensão no conto:

Hoje é sexta-feira, o melhor dia (...) Alguma coisa está me dizendo que a sessão da quatro de hoje vai ser sen-sa-ci-o-nal...(...) Pelo jeito, Geninha, vamos ter uma sessão de faroeste (...) Santa Luzia que ilumine minha visão que hoje vai ter, Geninha, vai ter... (...) Chiiii - respondeu a velha de óculos - pelo jeito vai começar uma nova Guerra do Paraguai... (...) Santa Luzia me diz que hoje tem coisa... (...) Vai começar a Sessão das quatro, Geninha! (Drummond, 1983, p. 116-24).

A perspectiva de Ciana é difusa, porque a continuação do conto sugere que ela também esteja acompanhando o casal que se aproxima para um encontro e, portanto, a Sessão das quatro por ela referida pode ser tanto um "filme romântico" quanto um "bangue-bangue", até que ela chega à conclusão de que "Vai ser um bangue-bangue, Geninha (...) no melhor estilo..." (id., p. 125). Com isso, se torna difícil avaliar a ambiguidade de seu comportamento, resultante do procedimento oblíquo em relação ao distanciamento ou envolvimento com o acontecimento que ela presencia.

Seu posicionamento oscila, no plano das aparências, entre a alienação 
absoluta e o distanciamento cruel. A potencial alienação é motivada, entre outras razões, pela aceitação da situação como sendo uma narrativa fílmica e, a partir disso, pela projeção de sua própria vida como se fosse um filme também. Já se admitirmos que ela é consciente de sua condição em relação aos acontecimentos que presencia, veremos nela alguém cujo sentido ético e humanitário é posto de lado ou, ao menos, encontra-se cerceado por razões que, no texto, estão silenciadas, mas que são facilmente depreendidas quando se nota a ação dos militares como forma de poder e de violência cujo fim é a manutenção de si mesmos, isto é, do próprio poder sob o regime da ditadura militar, por meio da intimidação das testemunhas.

Essa ambiguidade em relação ao acontecimento observado é diferente no filme de Hitchcock, em que, reiteradas vezes, a enfermeira de Jeff (Stella) e, ainda, sua noiva Lisa o questionam sobre a ilegalidade da espionagem que ele está fazendo. Além disso, quando eles começam a perceber que o vendedor Thoward parece ter assassinado sua esposa, passam a investigar o caso com o claro objetivo de desvendá-lo e garantir a prisão do assassino.

Na verdade, tanto em "Sessão das quatro" quanto em Janela indiscreta, é possível depreender uma ação simbólica de violência relacionada a, ao menos, um fim imediato - o silêncio como autodefesa, no conto; e a espionagem como defesa do outro, no filme. No filme, porém, há uma predominância do conteúdo referido (o crime) sobre a forma como ele é desvendado (também um crime, a espionagem), de modo que o senso ético é suficiente para absolver Jeff de suas culpas e reconhecê-lo por ter feito justiça. A punição que lhe cabe surge como consequência de suas próprias ações: ao ser atirado pela janela, ao final, em luta contra Thoward, ele fratura, também, a outra perna, como se pode ver na cena final do filme.

Já no conto de Drummond, o que adquire ênfase é a ambiguidade da própria linguagem, que se mostra, revelando não os mistérios do crime que Ciana vê, mas o processo de significação engendrado por sua relação com o real, e os limites desse real enquanto meio, no conto, para se chegar a um determinado fim. No filme, o fim maior da espionagem de Jeff é a justiça; no conto, não há um fim claro e explícito no ato de Ciana de assistir aos acontecimentos da praça (a menos que tomemos a diversão alienada como seu fim último), só um meio: a linguagem, que aí, é, também, acontecimento puro, isto é, "uma palavra não coercitiva, que não comanda nem pró́be nada, mas diz apenas ela mesma, (que) corresponderia a uma ação que mostra só a si mesma" (Agamben, 2004, p. 133). De certo modo, esse recurso é empregado por Roberto Drummond para representar, em 
seu texto, questões mais amplas da própria escrita narrativa e literária contemporâneas, que, por sua vez, remetem, ambas, à prática política. Sob essa acepção, contar histórias é sempre contar a história. Sua narração se faz "sem distinguir entre os grandes e os pequenos (acontecimentos), (e) leva em conta a verdade de que nada do que um dia aconteceu pode ser considerado perdido para a história" (Benjamin, 1986a).

No texto de Roberto Drummond, notamos, quanto à ação dos militares, que o poder age pela violência do feito, enquanto o poder de Ciana se manifesta pela ambiguidade de seu ato: "todos os fins naturais de pessoas individuais entram em colisão com fins jurídicos, quando perseguidos com maior ou menor violência" (Benjamin, 1986b, p. 162). E "o poder na mão do indivíduo (é) um perigo de subversão da ordem judiciária" (id., ibid.). De todo modo, a ação de ambos é uma ameaça, mas a ação militar, uma ameaça cujo fim é manter o clima de medo e, por essa via, garantir o poder de fato; a de Ciana, uma ameaça porque se mostra capaz de colocar em xeque a eficácia do poder-violência dos militares. Como observa Guelfi, tratando da obra de Roberto Drummond, "a consciência pós-moderna distingue-se por ter uma concepção do político como algo difuso. O poder e a luta são compreendidos como sendo dispersos por todo o domínio cultural e não apenas localizados nas esferas do estado e da atividade econômica" (Guelfi, 2007, p. 120).

Em Janela indiscreta, se bem que seja possível vislumbrar em Jeff ares de um Sherlock Holmes - aliás, uma das personagens do filme se chama Doyle e trabalha como detetive - , não são apenas razões pessoais que levam Jeff a insistir em querer resolver o caso "Thoward". São, também, a tematização e o questionamento de valores gregários de altruísmo, certo envolvimento com o próximo e os limites entre o espaço público e o privado que o levam a isso, o que fica claro, por exemplo, na cena em que após a morte (por estrangulamento) do cachorrinho que descobrira vestígios do crime do vendedor Thoward, a dona do animal, vizinha que vive com o marido no apartamento imediatamente abaixo da residência dos Thoward, faz um discurso, algo patético, no qual valores como a fraternidade e a preocupação e doação para com os vizinhos é posta em causa. O filme não faz apologia de tais valores, mas, ao contrário, aponta a fragilidade deles, no contexto de vida urbana, no século XX, pois, "quando a consciência da presença latente da violência dentro de uma instituição jurídica se apaga, esta entra em decadência" (id., p. 167).

Há, também, no conto de Roberto Drummond, uma instituição formalmente em decadência, pelo papel indefinido e duplo que assume: o estado democrático enquanto lugar de manutenção do bem estar social e da liberdade do sujeito. Não há um motivo objetivo para os militares 
assassinarem o negro, no conto. A violência dos militares visa à intimidação pública. Em momento algum se mostra problemático, para as duas personagens que, de certo modo, acompanham o crime, o fato de que elas estão testemunhando um crime. Aliás, a desumanização das relações interpessoais é reforçada, no conto, pela observação do narrador, já ao final da narrativa, quando este afirma que a praça está praticamente deserta, após a morte do rapaz, e os únicos que se chocam ou se aniquilam com a situação são dois desconhecidos da vítima: o homem do Volks areia e a mulher do Voks azul.

O comportamento ambíguo de Ciana, que parece sancionar a vitória da violência dos militares sobre o negro do Harlem caracteriza uma ação que não poder ser julgada, pois ela "consiste em reconhecer a nova situação como um novo 'direito', independentemente se ela necessita de fato alguma garantia para ter continuidade ou não" (id., p. 164). Sentindo-se inserida num espaço em que não há leis que garantam a sua integridade, Ciana assume novos parâmetros de ação, princípios éticos que se subtraem à ética tradicional, já que ela se flagra num meio em que os direitos individuais estão cerceados e tal situação está naturalizada, ou seja, (im) posta como se fosse desde sempre assim. Se a personagem age desse modo pela alienação, seu comportamento pode ser visto como passivo e comprova a eficácia do poder-violência mobilizado pelos militares. Se, por outro lado, ela estiver consciente da situação e agir do único modo que lhe parece possível, em tal contexto, então devemos admitir que, do mesmo modo que as formas narrativas sempre acompanharam as transformações das forças produtivas, como observa Benjamin (1985) retomando Marx, também a enunciação, nas formas narrativas, se transforma ou se situa dentro de determinados códigos e valores do direito que, por sua vez, são históricos. Num contexto de violência, "é a função, entretanto, de toda ação, distinta do simples comportamento, interromper aquilo que de outra maneira teria prosseguido automaticamente e, portanto, de forma previsível" (Arendt, 1970, p. 21). Desse modo, a posição de enunciação assumida pelo narrador enquanto enunciador também pode se relacionar à sua condição dentro de um sistema jurídico que dimensiona suas ações.

Em Janela indiscreta, por exemplo, há uma ética que se sobrepõe à obrigação de não adentrar a intimidade alheia e admite que, com o fim de evitar um determinado mal (a não punição do culpado), o erro (a espionagem de Jeff) seja anulado enquanto tal, e apenas o sentido salvador da ação de Jeff seja aprendido. Em "Sessão das quatro", não há força-de-lei capaz de julgar o comportamento das irmãs, pois elas se encontram num 
âmbito espacial e jurídico em que o público e o privado são esferas não claramente mensuráveis, sendo a janela o elo que conecta, simbolicamente, tais esferas: o público age sobre o privado, controlando, em parte, o comportamento de Ciana, e o privado assume dimensões públicas - o encontro amoroso do casal na praça é visto por Ciana, por exemplo.

Numa sociedade vigiada, e no conto, a vigilância está sempre presente, primeiro com os militares na praça, em seguida com os quatro militares na perua, tal ambiguidade aponta, ao menos, para dois caminhos: o primeiro é o da impossibilidade de o indivíduo expressar-se com alguma liberdade, em razão das ameaças permanentes que o autoritarismo acarreta. Em "Sessão das quatro", o cerceamento à liberdade de expressão já aparece sugerido no comportamento das duas senhoras, pois o risco de morte e de perseguição pela ditadura, que as personagens certamente conhecem, é depreendido, metaforicamente, pela presença dos militares, já que a narrativa aponta para o fato de que não é estranho ao cotidiano das duas personagens o tipo de acontecimento visto por Ciana, nessa praça. O segundo caminho é difuso, pois se articula à alienação ocasionada por uma vida regrada por produtos e bens culturais promovidos pela indústria cultural e pela cultura de massas ${ }^{6}$. As duas irmãs, no conto de Drummond, assumem, como modelo de interpretação para o que está acontecendo na praça, os modelos de filmes de ação e dos filmes românticos que estão acostumadas a ver pela televisão. A ambiguidade do comportamento de Ciana está, justamente, em que ela parece tão adaptada a tais "influências" que é capaz, inclusive, de simular uma confusão entre a sua realidade presente e um desses filmes. Se o simula realmente, sua perspectiva corresponde a um evento crítico, isto é, a um procedimento capaz de desautomatizar as ações que, no cotidiano, se naturalizaram e se tornaram simbolicamente violentas.

Nesse sentido, tal ambiguidade é um dos efeitos expressivos mobilizados por Drummond para denunciar as estruturas coercivas de força e de controle mobilizadas pelo governo militar brasileiro, durante a ditadura, para eliminar qualquer indivíduo considerado "risco nacional", por uma razão qualquer. O ridículo da situação no conto, no entanto, está no fato de não parecer existir nada que indique que o negro a ser assassinado represente ameaça alguma a ninguém.

O suposto risco parece dever-se ao fato de que ele se dá ares de felicidade, de liberdade e de desafio - porta um tênis vermelho e outro azul ${ }^{7}$,

${ }^{6}$ Há que notar que a literatura de Roberto Drummond se desenvolve exatamente a partir da tensão
entre consciência e iluminação implicada no procedimento de apropriação dos produtos massivos.
${ }^{7}$ Notamos o efeito irônico da descrição da ameaça que o negro representa, quando observamos 
parece ter vindo do Harlem ${ }^{8}$ e usa jeans desbotado. Suas características o situam próximo do que, nos anos 1960-70, se consideravam alternativas contraculturais em nome da liberdade. Aliás, uma das personagens do conto vê no negro uma "arrogância tão bonita" (Drummond, 1983, p. 120), que acaba associando-o a um santo ou mártir que "(veio) ao Brasil para encorajar os indecisos" (id., p. 125). Nesse sentido, o risco que o negro representa, na narrativa, está em que ele não parece estar tranquilamente submetido ao autoritarismo vigente e porta um vigor ${ }^{9}$ que representa um possível fator de desagregação da ordem estabelecida. Portanto, deve ser eliminado, de acordo com a lógica dos militares que o assassinam.

Ou seja, o crime, no conto, assume caráter explicitamente político, já que visa a sustentar, por meio da violência, uma ordem de violência, e o negro constitui-se, pois, num símbolo contrário a tal ordem coercitiva. E a ideia de liberdade posta em questão é, paradoxalmente, um simulacro, na medida em que nem o negro é, de fato, livre (está sendo vigiado), apesar de almejar ser, nem a referida sociedade, na narrativa, deixa ser plenamente livres os indivíduos inseridos nela, pois tenta modelar o imaginário dos indivíduos com sua fala mítica, isto é, política e ideologicamente situada, com objetivo de cercear o indivíduo e fazê-lo aceitar como natural uma determinada ordem estabelecida (Barthes, 1972). O mito procura apresentar como sendo naturais atos e acontecimentos que são, na verdade, construções histórico-ideológicas que visam ao estabelecimento ou à manutenção do poder de determinados grupos: no caso, a reificação do sujeito e a naturalização das forças e das formas do poder político para o controle social e a manutenção da ordem política. Nesse sentido, metaforicamente, a "sessão das quatro" já se tornou, para as duas irmãs, parte dos produtos que elas consomem sob o rótulo de diversão, em cujas bases

que ele é símbolo da ideia de liberdade que a sociedade norte-americana representada na narrativa (vermelho e azul, aqui, remetem à conhecida imagem do Tio Sam). Mas, por um lado, essa liberdade é impugnada e, por outro, são os valores dessa mesma sociedade livre que sustentam, no imaginário das duas irmãs, a espetacularização da vida cotidiana (pelas imagens do estrelato e dos filmes do cinema norte-americano).

${ }^{8}$ Harlem é um bairro de Nova York, conhecido por ser um centro comercial e cultural afro-americano. ${ }^{9}$ Segundo Arendt,"vigor designa inequivocamente alguma coisa no singular, uma entidade individual; trata-se de uma qualidade inerente a um objeto ou pessoa e que pertence ao seu caráter, a qual pode manifestar-se em relação a outras coisas ou pessoas, mas que é essencialmente independente deles. O vigor do indivíduo mais forte pode sempre ser subjugado por aqueles em maior número, que frequentemente se unem para aniquilar o vigor precisamente por causa de sua independência característica. A hostilidade quase que instintiva dos muitos em relação ao indivíduo isolado foi sempre, de Platão a Nietzsche, atribuída ao ressentimento, à inveja dos fracos pelos fortes, mas essa interpretação psicológica não atinge o âmago da questão. Está na natureza de um grupo de seu poder voltar-se contra a independência, a qualidade do vigor individual” (Arendt, 1970, p. 28). 
estão as formas de organização, explicação e sustentação da ordem social vigente, isto é, uma mitologia (Barthes, 1972) cujo fim último é interpelar os indivíduos por ela alcançados e sustentar o poder que lhes é (im)posto.

No conto de Drummond, o desmascaramento dessa mitologia se dá, justamente, na medida em que vão sendo flagradas, na narrativa, as formas por meio das quais os indivíduos vão sendo sitiados, literal e imaginariamente, o que se mostra, no texto, com a mesma naturalidade com que se pode acompanhar o encontro do casal formado pela mulher do Voks azul e o homem do Voks areia, encontro a que Ciana assiste como um filme romântico. No âmbito da história narrada, ao mesmo tempo em que o negro se aproxima da praça, os quatro militares da perua vão contornando a praça, em busca da melhor posição para atacar o rapaz. Quanto às senhoras, elas vão se envolvendo imaginariamente com a situação, ao passo que a velha de óculos vê e relata à irmã, simultaneamente, a aproximação do casal (portanto, se apega à motivação erótica) e, também, o encantoamento do negro pelos militares. Tal procedimento, sob o olhar da velha de óculos, equivale à justaposição de sintagmas alternantes (Reisz; Millar, 1978), pois ora ela olha o casal ora o negro e, posteriormente, situa tanto o casal quanto o negro no mesmo espaço: quando o negro é morto, $\mathrm{o}$ casal se prostra, na última cena, chorando, diante da vítima.

A estratégia de escrita empreendida no conto consiste em, entre um e outro trecho circunscrito num mesmo espaço de tempo, apresentar, sempre, todas as personagens envolvidas consciente ou inconscientemente no evento, a partir de suas distintas posições, de modo a relacioná-las a um mesmo acontecimento e, ao mesmo tempo, fragmentar o conhecimento do leitor em relação a elas. Tal estratégia aponta, ainda, para os limites do conhecimento que elas têm das situações vivenciadas pelos demais indivíduos ao seu redor. O efeito de suspense resultante é corroborado por certa aura de mistério criada em torno da imagem do negro do Harlem. Seu tom desafiador e livre desperta nas personagens que estão na praça, a mulher do Volks azul e o homem do Volks areia, uma relação de admiração e, mesmo, de culto, e é esse mal-estar que ele provoca que justifica, sob a ótica dos militares, a ação ofensiva adotada contra ele, pois o sentem como uma ameaça.

Em Roberto Drummond, o efeito de estranhamento provocado por um ser, seja representação de humano ou de animal, resulta do emprego de um procedimento escritural que aparece em várias de suas narrativas e consiste numa espécie de presença difusa do inexplicável, por vezes afim ao maravilhoso, que foge ao que pode ser racionalizado e ocasiona o malestar que deflagra o conflito dramático em suas narrativas. É o que ocorre, por exemplo, no romance Sangue de Coca-cola (1980), no qual uma profecia 
- no dia em que a borboleta verde da felicidade passasse pelo céu do Brasil muitas coisas mudariam - faz com que se arme um sistema de vigilância monumental ao território nacional que ganha matizes de absurdo, desencadeando a narrativa que, de fato, adquire um matiz insólito pelo estado de êxtase que a borboleta, ao passar, provoca nas personagens. Algo semelhante ocorre no conto "Um homem de cabelos cinzas", do livro A morte de D. J. em Paris (1975), no qual se arma um grande esquema de vigilância a um homem de cabelos cinza, em razão de seu "comportamento suspeito", num aeroporto, mas nenhum agente tem coragem de descobrir o que ele tem numa caixa que leva consigo e observa com ares de felicidade, até que, ao final, uma aeromoça desavisada quanto ao grupo de 58 agentes distribuídos pelo avião se aproxima do homem de cabelos cinza e faz o que ninguém teve coragem: olha a caixa e descobre que dentro dela havia, apenas, um fio de cabelo loiro de mulher. Em "Sessão das quatro", do mesmo modo que em "O homem de cabelos cinzas", não há insólito, mas a felicidade inexplicada do rapaz e seu ar de liberdade cumprem essa mesma função anteriormente referida, tornando insustentável a tranquilidade ao redor e, em consequência, desencadeando a absurda a vigilância que culmina com o crime contra o negro.

E, nisso, já podemos notar uma diferença importante no que caracteriza as representações da vigilância em Janela indiscreta e em "Sessão das quatro". No filme, apesar de o crime ser um dado concreto para o protagonista, pois ele está ciente de que se trata de um assassinato, a indiscrição de seu olhar curioso e ávido por descobertas se identifica, também, à percepção do erotismo e dos acontecimentos mínimos do cotidiano de seus vizinhos, o que a torna potencialmente mais lúdica, também, como podemos ver na sequência de cenas iniciais do filme. Sua ação de espionar os vizinhos se inicia, na verdade, como uma atividade lúdica e bisbilhoteira, sem maiores pretensões aparentes, e o fato de ele acabar por desvendar um crime só se torna intencional quando suas observações lhe oferecem pistas suficientes para desconfiar do senhor Thoward. É o comportamento do senhor Thoward que incita Jeff a dar continuidade à investigação: Thoward se mostra desconfiado, atento em relação a um cachorrinho que fareja algo num canteiro do jardim, e, misteriosamente, o cãozinho morre estrangulado. Isso leva Jeff a observar certas fotos que tirara do canteiro dias antes e a descobrir, por contraste, que Thoward tinha mudado de lugar as plantas de seu jardim. Tal fato alimenta as suspeitas de Jeff sobre o assassinato da esposa de Thoward e um possível enterro clandestino do corpo no jardim. Ou seja, depois de ter percebido o mistério, Jeff brinca de detetive, e soluciona, realmente, o caso, apesar de se confundir com algumas das pistas que encontra, acertando, porém, na interpretação de outras. 
Já em Drummond, o não ver ou não saber a realidade imediata do que acontece na praça ou simular tais efeitos, por parte da personagem Ciana, faz com que sua perspectiva - que, inicialmente, tem apenas o apelo à diversão, como se assistisse a um filme televisivo - adquira o tom de testemunho difuso, mas inquestionavelmente politizado, da barbárie instalada na imanência da vida cotidiana, no Brasil, sob o regime da ditadura militar.

Em sua linguagem, o conto representa algumas das tensões presentes no meio social representado na narrativa, como o medo, os silêncios decorrentes desse medo e das arbitrariedades do poder de fato, bem como as estratégias de coerção e de tentativa de alienação compulsórias dos indivíduos, por meio de um processo de naturalização da dominação e do controle pela força física ou simbólica. É o que representam, respectivamente, o assassinato do negro e o hábito com que as senhoras parecem assistir a ele, como se fosse mais um filme ao longo da semana. A vigilância deixa de ser, pois, apenas uma ação particular (o olhar das senhoras, em Roberto Drummond) e se expressa de distintos modos, constituindo a regra geral na qual a sociedade representada na narrativa centra sua estratégia de difusão e controle ideológico ${ }^{10}$.

Em tal contexto, vigiam-se os comportamentos, por meio da tentativa de torná-los habituais, e vigiam-se os próprios vigilantes, que já não têm controle pleno sobre seu imaginário nem sobre seu dizer, apesar de agirem de um modo ambíguo que não nos permite afirmar que sejam totalmente cativos à estratégia de controle engendrada pelas esferas dominantes do poder. No conto, Ciana (vigilante), apesar de sua posição cênica privilegiada, também é vigiada, de certo modo, pelos militares que estão na praça e que representam a ordem e a coerção física, aí, e estes, por sua vez, estão imersos numa estrutura de poder na qual não têm controle pleno do processo em que estão envolvidos, pois são controlados (vigiados) por seus superiores (vigilantes). Observam-se, portanto, no texto de Roberto Drummond, relações que revelam movimentos e articulações constitutivos das forças políticas que, por sua vez, acompanham as transformações do conceito e do papel do Estado e de seus códigos de conduta, no caso, associados à história política do Brasil da segunda metade do século XX.

Quanto a esse aspecto, o conto e o filme em análise apresentam uma diferença formal importante: no filme, a vigilância é dada de imediato como algo visível tanto por parte do protagonista (Jeff) quanto do especta-

\footnotetext{
${ }^{10}$ Parece tratar-se de um aspecto não só da sociedade brasileira então sob o governo militar, mas, num âmbito mais amplo, talvez das sociedades ocidentais, ao menos desde a primeira Guerra Mundial, num processo crescente de naturalização, para o qual a presença dos media colaborou. Se, por um lado, ela serve de denúncia das ações do poder-violência, por outro, ela pode, por vezes, espetacularizá-lo.
} 
dor; já no conto ela está escamoteada no próprio acontecimento - a morte do rapaz numa emboscada, que revela todo um aparato militar, investigativo e político envolvido. Isto é, em Janela indiscreta, pela posição cênica ocupada por Jeff (o interior de seu apartamento) em relação aos vizinhos observados, nota-se que há uma cisão entre o observador e o observado, que, se por um lado, limita a visão do observador, por outro, lhe oferece meios para um maior distanciamento crítico em relação ao que ele vê, e o protege. O próprio enquadramento ratifica esse efeito, na medida em que Jeff, de sua janela, olha o espaço externo e vê o interior das demais casas através das janelas delas. Ao mesmo tempo em que cada uma dessas janelas desvenda mundos, a presença delas marca, reiteradamente, onde começa e onde se limita cada um desses mundos. Mesmo quando Jeff ainda não tem provas de que o vendedor Thoward assassinara a esposa, e admite poder ter falhado ou ficcionalizado suas visões, ele se mostra capaz de racionalizar até que ponto tal ficcionalização seria possível. Sabe que pode ter cometido um erro de interpretação das pistas que tinha, mas sabe que são realmente pistas do que parece ser um crime, mesmo que, talvez, não seja.

Já Ciana, no conto, toma o acontecimento que vê como sendo um filme, sem problematizá-lo explicitamente. Se estiver consciente dos acontecimentos, não deixa isso explícito para o leitor. Se não estiver, é tão vítima do controle e da vigilância instaurados quanto a mulher do Volks azul, o homem do Volks areia e o negro morto. Em certo sentido, é tão agredida quanto as demais personagens. Como não pode diferenciar-se plenamente de seu universo (seja pela possível alienação seja para defender-se), ela também se mutila enquanto indivíduo: não pode ter voz própria e não pode ver clara e comodamente o mundo que tem diante de si, do qual faz parte. Portanto, se cria, no conto, uma tensão entre a perspectiva da personagem e a que se projeta para o leitor, que tanto pode aceitar ingenuamente os acontecimentos quanto pode assumir a posição de um terceiro observador, para notar a complexidade do processo desencadeado.

\section{Estados de exceção: janelas indiscretas e olhares oblíquos}

Em ambos os textos, os processos narrativos são complexos, pois as instâncias narrativas não estão identificadas com a perspectiva de, apenas, uma personagem nem com um narrador exclusivamente externo ao narrado. Também, em ambos os casos, os observadores (Jeff e Ciana) assumem, do ponto de vista enunciativo, um lugar jurídico não respaldado por nenhuma lei: Jeffries age sob uma suspensão temporária da constitui- 
ção, que proíbe a intromissão na intimidade alheia, enquanto Ciana está imersa num vazio anômico em que as condutas de lei sequer são postas em questão. É nesse sentido que podemos nos referir a ambos os contextos como característicos de um estado de exceção (simbólico, no caso de Jeff; de fato, no caso de Ciana) e propor que o lugar enunciativo ocupado pelas personagens é respaldado pela condição (não-)jurídica ${ }^{11}$ de dito estado ${ }^{12}$.

Essa "exceção naturalizada" possibilita, por sua vez, a conformação de novos lugares jurídicos (ou juridicamente nulos) e enunciativos que representam, de certa forma, o modo que os indivíduos representados em cada uma das narrativas encontra para agir criticamente, num universo em que a lei e seus princípios éticos estão fora da lei.

Nas narrativas em questão, tais lugares enunciativos se associam às possibilidades enunciativas de uma voz de narrador do relato, que se relaciona a uma focalização. Jeff, em Janela indiscreta, e Ciana, em "Sessão das quatro", assumem, por vezes, a função de narrador, nos relatos de que são personagens. Ele o faz sempre que a câmera está identificada com seus olhos, ela enquanto personagem que conta a sua irmã Geninha os acontecimentos que vê da janela, funcionando, ao mesmo tempo, como narrador-testemunha do que assiste, na praça. Só eles têm o poder de

\footnotetext{
${ }^{11}$ A adoção da expressão “(não-)jurídica”, aqui, se deve a que o estado de exceção consiste, exatamente, na suspensão das jurisdições vigentes, em nome da manutenção da ordem.

${ }^{12}$ É necessário observar, aqui, então, que não se deve confundir “estado de exceção” com ditadura, apesar de que, muitas vezes na historia da humanidade, as ditaduras se mantiveram sob regime de exceção. Como propôs Benjamin: “A tradição dos oprimidos nos ensina que o 'estado de exceção’ em que vivemos é a regra geral” (Benjamin, 1986a, p. 226). Se, por um lado, as teses sobre o conceito de história propostas pelo autor não podem ser dissociadas do contexto de horror do nacional-socialismo alemão e do estado da Europa beligerante em plena Segunda Guerra Mundial, por outro, se o autor tivesse vivido todo o século XX, provavelmente confirmaria sua proposição. Há, na história ocidental, uma série de manifestações capazes de constituir, talvez, uma tradição do estado de exceção, dando forma legal àquilo que não pode ter forma legal, por sua própria natureza de não pertencimento ao corpo jurídico (Agamben, 2004). Um exemplo disso é o carnaval na Idade Média, estudado por Bakhtin (1996). Ele não pode ser julgado como transgressivo ou permissivo, porque se instaura num espaço em que o corpo de leis não tem validade. A prática do direito romano, por sua vez, também já apresentava uma instituição que pode ser vista, hoje, como a gênese do estado de exceção, o iustitium, que corresponde à interrupção do direito em nome do próprio direito, para salvá-lo (Agamben, 2004). Se observarmos, também, a política de estado mais recente, nos lembraremos de que, após o ataque ao World Trade Center, em 2001, o então presidente dos Estados Unidos, Jorge W. Bush, passou a referir-se, diversas vezes, em público, como sendo o "comandante em chefe do país”, título cujo caráter bélico se propõe conferir ao titular poderes absolutos de decisão e ação, em nome da ordem, sem a necessidade de acionar os órgãos democráticos associados ao governo. Parece ser recorrente, ao longo da história do Ocidente, uma série de marcas da indeterminação entre a democracia e o autoritarismo que caracterizam o estado de exceção (id.), tanto em suas estruturas sócio-políticas quanto em suas matrizes culturais. O que Benjamin observa é o fato de que, ao longo do século XX, tal exceção se tornou regra (e as experiências latino-americanas da segunda metade do século XX o comprovam facilmente).
} 
dizer sobre o que veem. É como se cada um exigisse: “Deixem-me olhar para que você, leitor, também possa ver" (Santiago, 1989, p. 45). Ocorre, porém, que Jeff, apesar de também se permitir bisbilhotar espaços que não lhe pertencem, mostra-se permanentemente ciente de não pertencer aos espaços que vê. Sabe que está violando um código de conduta. O próprio enquadramento por meio do qual vê a privacidade de seus vizinhos, pelas janelas de cada apartamento, enfatiza os limites entre um espaço e outro.

Ciana, por sua vez, ocupa uma posição que é a de alguém que está fora do espaço do acontecimento e, ao mesmo tempo, pertence ao acontecimento. Enquanto, em Janela indiscreta, descobrimos o flagrar (por parte de Jeff) de um espaço protegido, em "Sessão das quatro" encontramos um espaço em que a lei inexiste enquanto ideia, portanto, ela não é violada ou desrespeitada. Em ambos, no entanto, há uma semelhança: não há democracia plena como ideia ordenadora desses espaços enunciativos, pois uma "democracia protegida" não existe. Portanto, em ambos os casos notamos marcas de instâncias político-sociais e culturais cuja tendência à exceção está, simbólica ou concretamente, presente. Jeff e Ciana agem politicamente, mas Jeff ainda age em nome de uma política que se propõe ou acredita ver o mundo com objetividade, que é o que lhe permite julgar de modo racional o crime de Thoward. É nesse sentido que, enquanto forma narrativa, ele se aproxima do narrador referido por Benjamin como sendo o narrador do romance, aquele que se baseia em fatos e informações, mesmo que estes não sejam o resultado de suas vivências pessoais. Por não estar ligado a tais fatos pela experiência, ele está protegido das suas consequências éticas e morais.

Já Ciana é flagrada numa sensação de "êxtase-pertencimento", para usar, aqui, uma expressão de Agamben (2004), que a impede de decidir com precisão e clareza sobre o que vê. Ela apenas vê. Sua voz é a de quem não porta condições de assumir a palavra como experiência nem como informação e "cria espaço para a ficção dramatizar a experiência de alguém que é observado e muitas vezes desprovido de palavra" (Santiago, 1989, p. 44). Tal estrutura corresponde, integralmente, ao estado de exceção. Sua ambiguidade provoca reações que anulam o indivíduo totalmente, impedindo-o de decidir claramente sobre si e sobre o outro. Empolgação, emoção, sedução, são essas as reações de Ciana, nenhuma delas comunicável, nenhuma delas distanciada, "se trata de um diálogo-em-literatura (isto é, expresso por palavra) que, paradoxalmente, fica aquém ou além das palavras" (id., ibid.).

Se analisarmos, então, a observação de Walter Benjamin (1985), se- 
gundo a qual os soldados que voltavam da (primeira) guerra, estavam mais pobres de experiência comunicável, e não mais ricos, como era de se esperar, perceberemos que o estado de exceção (de fato ou simbólico), enquanto estrutura político-discursiva, cria suas próprias regras enunciativas. No caso referido por Benjamin, o silêncio dos soldados da guerra corresponde ao princípio do direito positivo de que a violência não se comunica com fins de ratificar o poder, pois não se deve mobilizar um meio injusto para se alcançar um fim determinado. Já em relação à personagem Jeff, há, pois, uma nítida diferença de princípios, visto que "mais do que tornar lícito o ilícito, a necessidade (funciona) aqui como justificativa para uma transgressão em um caso específico" (Agamben, 2004, p. 40-1), que é o desvendamento do crime. Mas, enquanto ato, Jeff apenas preludia a naturalização da ação no âmbito da não lei, a qual, por sua vez, aparece como regra em "Sessão das quatro". Nesse conto, essa naturalização está presente de vários modos: a) os militares agem de forma arbitrária, tratando o negro do Harlem sem qualquer princípio de conduta ou causa aparente; b) Ciana conta à irmã o que vê como se fosse uma ficção; e c) o casal que testemunha o assassinato é aproximado como marido e mulher, na cena final da narrativa, apesar de que o homem do Volks areia e a mulher do Volks azul não formam, juridicamente, um casal, mas, sim, mantêm uma relação de ordem amorosa proibida (ainda que apenas no nível do desejo).

É significativo que, no filme, a idéia de intimidade seja posta em causa (Rear Window é o título original), ao passo que, no conto, há um vazio e uma interrupção do direito que anulam o estatuto jurídico de todos os envolvidos, e já não se pode divisar as instâncias do que é público e do que é privado. Tal situação cria, em Ciana, a impossibilidade de decidir-se. O poder-violência que está na base desse comportamento se deve a que ela age de modo indeterminado e num lugar indeterminado, mas o faz por imposição externa, ocupando uma posição juridicamente inexistente, pela impossibilidade de ocupar um lugar jurídico, de fato, já que está sob estado de necessidade. Esse posicionamento aponta para o fato de que enunciar criticamente num estado de exceção representado (simbólico ou de fato) exige que a linguagem seja mobilizada sem fins imediatos, como acontecimento politizado capaz de gerar conhecimento crítico e, talvez, reconectar o presente às suas temporalidades correlatas ao longo da história.

Trata-se, pois, de um recurso violento também, que busca, nas possibilidades expressivas da linguagem artística de cada uma das narrativas, meios para desautomatizar, no plano da representação, a violência da lin- 
guagem dos meios de coerção empregados para a manutenção de uma determinada ordem jurídica e política. A justificativa para um recurso à violência como alternativa de enfrentamento à violência está no valor instrumental que ela assume, operando de modo a, potencialmente, ampliar a força do indivíduo, para alcançar um determinado objetivo (Arendt, 1970). De certo modo, essa é, também, uma medida extrema em nome da subjetividade do indivíduo, mas "a questão é que, em certas circunstâncias, a violência - atuando sem argumentos ou discussões e sem atentar para as consequências - é a única maneira de se equilibrar a balança da justiça de maneira certa" (id., p. 33).

Comparando, uma vez mais, o filme ao conto, notamos leves alterações nas ações das duas personagens centrais e, ao mesmo tempo, mudanças profundas no modo como elas encaram os acontecimentos e agem diante deles. De certo modo, ambas as personagem representam extremos de um mesmo processo, que é o de permanente vigilância e controle como bases ordenadoras das sociedades capitalistas pós-50 (ou, mesmo, do século XX). As diferentes respostas por parte das personagens - a afirmação positiva de Jeff e a consequente resolução do caso, pautando-se numa orientação racionalista; e a ambiguidade do comportamento de Ciana, entre alienada e defensiva - apontam para distintas formas de sabedoria possíveis para se legitimar sua enunciação sob vigilância, no contexto em que se encontram as personagens. Como observa Silviano Santiago, "pode-se encará-la com a sabedoria da experiência ou com a sabedoria da ingenuidade" (Santiago, 1989, p. 47). E este último modo parece ser o mais coerente com o contexto de ameaça do poder-violência imanente a um estado de exceção. Nele, fala-se por interposta pessoa, isto é, delega-se a voz ou o olhar ao outro, para que, por meio do outro, o indivíduo possa agir política e criticamente. Esse é o estatuto jurídico da enunciação sob estado de exceção, pois só se está protegido quando não se é de modo pleno, e tal condição fomenta um novo tipo de experiência, da ordem do olhar. Essa experiência está identificada, ainda, na esfera representacional, às possibilidades expressivas da linguagem cinematográfica.

Há que observar que o escamoteamento da fala no conto de Roberto Drummond manifesta um procedimento reiterado em sua obra. Suas personagens, em geral identificadas com o leitor comum, vivenciam situações estranhas (como Dôia, em "Dôia na Janela", do livro A morte de D. J. em Paris), cuja ambiguidade sugere tanto a incapacidade crítica da personagem quanto um modo obtuso de expressar a diferença e os silêncios significativos numa sociedade não integrada, plenamente, à democracia. O próprio silêncio, ao final de "Sessão das quatro", porta essa ambiguidade: Medo? Defesa? Aniquilação? De certo modo, 
O totalitarismo moderno pode ser definido, nesse sentido, como a instauração, por meio do estado de exceção, de uma guerra civil legal que permite a eliminação física não só dos adversários políticos, mas também de categorias inteiras de cidadãos que, por qualquer razão, pareçam não integráveis ao sistema político. (Agamben, 2004, p. 13)

Nesse contexto, agir de modo oblíquo, talvez fingido, como nos sugere a narrativa de Drummond, pode ser uma alternativa para o indivíduo se proteger e para proteger os seus das ameaças que cerceiam sua fala e sua existência simbólica ou concreta, pois, sob estado de exceção, ao mesmo tempo em que se questiona a consistência do espaço público, a consistência do espaço privado também é neutralizada, e o indivíduo só pode assumir-se, com segurança, em parte. O modo violento por meio do qual essa alternativa se concretiza como linguagem atende à necessidade de efeito imediato a que se vincula, no âmbito da enunciação. Na inflexão da própria voz, potencialmente presente em cada enunciação, como linguagem cuja forma e a substância são capazes de salvar a individualidade do enunciador,

A violência, sendo instrumental por natureza, é racional até o ponto de ser eficaz em alcançar a finalidade que deve justificá-la. E já que quando agimos, jamais saberemos com certeza quais serão as eventuais consequências, a violência só pode manter-se racional se buscar objetivos a curto prazo. A violência não promove causas, nem a história nem a revolução, nem o progresso, nem a reação, mas pode servir para dramatizar reclamações trazendo-as à atenção do público. (Arendt, 1970, p. 50)

Sob tal condição para a produção dos discursos que, cada um a seu modo, se apresentam nas duas narrativas em análise, o indivíduo representado se obriga a agir como achar melhor (em Hitchcock) e, em último caso, a não agir (em Drummond). Do ponto de vista jurídico, esse enunciador "não executa nem transgride, mas inexecuta o direito" (Agamben, 2004, p. 78) e, portanto, cria um verdadeiro estado de exceção, também, no âmbito da linguagem, potencialmente capaz de produzir conhecimento e consciência históricos para os indivíduos envolvidos e, ainda, para o leitor, o que configura o espaço discursivo necessário à criação de uma narrativa aberta.

Como se pode observar nas narrativas em questão, os cortes cênicos operados, a mobilidade da câmera enquanto instância de narração e as quebras das relações objetivas entre um plano e outro ou uma cena e outra constituem fragmentos aparentemente livres que acabam por referir a incomunicação e o isolamento da personagem Jeff, no filme, e das duas 
senhoras, no conto. Jeff e Ciana são mais importantes como narradores do relato do que como personagens dos relatos que integram. E Ciana é mais importante como narrador do que o próprio narrador do conto. Podemos observar, então, que, no conto, o narrador se subtrai à função de mediador, transferindo-a para um espaço oblíquo, que poderia ser caracterizado como sendo um espaço discursivo sem direito, um espaço de anomia, no qual a desativação ou suspensão da distinção entre público e privado torna impossível a assunção da autoridade pelas esferas subjetivas envolvidas, inclusive o próprio narrador. Nesse sentido, Jeff se distancia de Ciana, pois ele, mesmo quando não narra, é autônomo enquanto personagem; Ciana, por sua vez, é significativamente nula fora de seu papel de narradora-mediadora observando na janela. Como narradora, ela transmite uma "sabedoria" que é decorrência da observação de uma vivência alheia a (ela), visto que a ação que narra não foi tecida na substância viva de sua existência. Nesse sentido, (ela) é o puro ficcionista, pois tem de dar "autenticidade" a uma ação que, por não ter respaldo na vivência, estaria desprovida de "autenticidade". (Santiago, 1989, p. 40)

Essa instância narrativa identificada, por vezes, ao narrador do relato, cujos atos não são transgressivos nem ordenativos, enuncia de um não lugar, o que a torna vulnerável enquanto representação, pois, se por meio dela, se fala a partir de lugar algum, sua existência parece questionável, já que os indivíduos que ocupam tal instância só existem enquanto ficção e em relação às ficções que criam. O comportamento de Ciana, por exemplo, se relaciona, também, à existência ambígua dos indivíduos que ela representa, silenciados enquanto voz num espaço social regido pelo estado de exceção. Por um lado, a representação do estado de exceção simbólico ou de fato cria um não lugar enunciativo cuja ambiguidade torna difusas e potencialmente nulas as ações dos indivíduos em sua esfera de existência, no universo em que estão inseridos. Por outro lado, por não ocupar um lugar fixo dentro desse espaço discursivo, tal instância enunciativa pode funcionar, também, como uma ameaça e como esfera de ação essencialmente politizada. Seu alcance, contudo, mantém-se discutível e sua eficácia pode parecer algo duvidosa, pois pode ser apropriada por todas as instâncias tensionadas, inclusive as opressoras.

Como estratégia de poder contra o poder-violência que passa a ameaçar o indivíduo permanentemente, porque não é dito, mas ecoa nos atos e nas instituições sociais de seu universo de relações, tal procedimento constitui um modo de capturar/aprisionar o não linguístico. Ciana se extrai da ação narrada, em atitude semelhante à de um repórter ou 
de um espectador. Se, por um lado, ela não mobiliza os acontecimentos como experiência, a vivência que ela mobiliza constitui-se numa experiência dramatizada, em que ela atua permanentemente com oblíqua dissimulação.

Tanto Janela indiscreta quanto "Sessão das quatro" representam, portanto, enunciações sitiadas, cada uma a seu modo, em que o sujeito do discurso só pode enunciar e enunciar a si mesmo sob condições ilícitas ou não lícitas. Em Hitchcock, porém, a violência é jurídica (houve, também, o crime da espionagem) e corresponde a um meio que leva a um fim buscado. Em "Sessão das quatro", no entanto, a enunciação sob o signo do "êxtase-pertencimento", por Ciana, funda uma realidade que só existe como resultado de uma ação de violência pura. No sentido em que Benjamin pensa uma "linguagem pura", tal violência pura equivale à violência da linguagem humana em seu potencial salvador, isto é, enquanto meio que comunica imediatamente a si mesmo, sem fins imediatos e, por isso, é capaz de tensionar e, talvez, fragilizar as determinações e as coerções que procuram condicionar a linguagem às ações da violência (do poder).

Em certo sentido, a linguagem dos contos de Roberto Drummond, que já foi caracterizada por Guelfi (2007) como sendo esquizofrênica, é uma linguagem também anômica, sua "não norma de conduta" a coloca numa posição que procura desmascarar os cerceamentos diários às falas individuais de suas personagens e, talvez, salvar estilhaços de sua subjetividade.

\section{Fechando as janelas}

As questões centrais que nos guiaram até aqui nos permitem esboçar, então, algumas considerações cujo alcance se propõe mais como reflexão do que como constatação, mas que (acreditamos) podem ser produtivas para se pensar, também, algumas narrativas dos anos 1970-80 e, mesmo, da literatura contemporânea posterior.

O narrador, enquanto autoridade e voz que pode identificar-se com um ou mais de um ente do discurso narrado, se instaura em um lugar enunciativo que é correlato a um estatuto jurídico determinado, no plano da representação. O narrador contemporâneo, que a crítica chama, por vezes, de pós-moderno, encontra na ficcionalização de si uma estratégia produtiva para criar um lugar enunciativo. Quando se observa que os indivíduos, nas sociedades ocidentais modernas e contemporâneas, têm vivido sob permanente vigilância do poder-violência, no que poderia caracterizar um estado de exceção, que pode ser tanto simbólico quanto de fato, nota-se que esse lugar enunciativo só se legitima, realmente, enquanto se enuncia, isto é, enquanto linguagem em ato. Portanto, é tão ficcional 
quanto o narrado, e é correferente, de certo modo, das estruturas sociais em meio às quais se desenvolve.

Uma vez que a vida social se presentifica na literatura por meio de sua linguagem (Tinianov, 2004), esse é um modo legítimo de o escritor se pronunciar em relação à ordem dos acontecimentos políticos e ideológicos que o cercam: Ciana fala a linguagem da necessidade (da exceção), porque somente por essa via poderá escapar da coerção repressora da violência de fato e da alienação da violência que os modelos culturais massivos que ela tem por modelo podem lhe impor. Tal possibilidade de expressar-se conotativamente ao mesmo tempo em que se expressa denotativamente corresponde a uma aproximação, pela personagem Ciana e, talvez, por diversas obras da literatura contemporânea, à linguagem cinematográfica, cujo sintagma é, sempre, denotado e conotado ao mesmo tempo, ou seja, é sempre referente de si mesmo e potencialmente ambíguo em seu dizer.

O comportamento de Jeff, em Janela indiscreta, por sua vez, é diferente. Ele não assume a exceção concretamente, mas toma a realidade como marcada por vazios de direito temporários, mediante os quais um ato de justiça pode ser maior do que uma violação à norma. Seu gesto aponta para o caráter não livre e não democrático desse direito, que tenta vincular a necessidade a uma espécie de poder jurídico originário, fundando sua própria mitologia, no sentido de "fala", conforme propõe Roland Barthes (1972). Desse modo, tal enunciador é soberano, dentro dos limites do que vê. Esse parece ser, pois, o status jurídico do narrador do romance tradicional de base realista, sua voz é o mundo, não porque ela o cria, mas porque é ela que o representa, sem questionamentos sobre o modo como o faz e o legitima. De certo modo, seu saber se baseia na necessidade de encontrar uma explicação para um acontecimento real ou ficcional representados.

E se nos for cabido, ainda que brevemente, pensar sobre o lugar jurídico do narrador tradicional referido por Benjamin (1985), tal narrador se situa fora do direito positivo, mas, por outro lado, assume, também, uma mitologia, de modo que, por meio dela, funda, organiza e sustenta o universo do narrado, com a autoridade de quem o experimentou. Diferenciase dos dois anteriores, contudo, porque se fundamenta na experiência coletiva e, por isso, se torna sujeito do saber prático que, como tal, está fora do âmbito do que pode ser julgado em abstrato. Ele é fundador do poder, $\operatorname{logo}$, não pode estar sujeito ao poder do direito.

Podemos, por fim, notar, pelo cotejo dos objetos analisados, que a assunção da exceção como sendo a regra, na narrativa contemporânea (de Roberto Drummond) é resultado de um processo que pode ser observado na narrativa desde meados do século XX (em Hitchcock, por exemplo), 
ao menos, e, como fundamento, existe nas produções culturais e jurídicas do Ocidente há séculos. A assunção da tese de Benjamin sobre a exceção como sendo a regra, porém, aponta para a crise epistemológica da própria condição do narrador (como ideia), cuja autoridade precária, contemporaneamente, o obriga a simular sua própria existência para conferir algum efeito de realidade a ela (internamente ao relato), pois ele só existe como manifestação textual.

Tal fato, porém, pode ser revificador, pois, na medida em que a possibilidade de transmissão da experiência plena do narrador tradicional se perdeu, o utilitarismo da narrativa passou a ser, também, um meio de coerção (mobilizado, por exemplo, pelos media e pelos discursos do poder em geral). No entanto, a desintegração do narrador, não como elemento narrativo, mas como ideia de autoridade sobre a experiência e o narrado, não impede a narrativa de buscar meios de expressão de uma voz crítica. Permanece vigente, na contemporaneidade, um narrador que, mesmo restrito à materialidade do relato, coexistindo apenas internamente a ele e fragilizado enquanto ideia, é, potencialmente, capaz de mobilizar a linguagem como poder de subjetivação que pode desautomatizar a percepção do indivíduo em relação aos mitos ou os atos de violência que dão sustentação à ordem social de barbárie por vezes estabelecida. Desse modo, ele se mostra capaz de apontar para além do texto, para a leitura e a interpretação enquanto práticas sociais constitutivas de significação da própria narrativa da história.

Tanto em Janela indiscreta quanto em "Sessão das quatro", mas de modo mais matizado no primeiro, essa leitura aberta nos permite perceber que a ficção tem sido a instância jurídica norteadora de nossa era e, logo, a arte consciente dessa condição tem muito a nos ensinar, na medida em que aponta para as novas formas de narratividade que estão sendo gestadas no tecido social e para o(s) diálogo(s) que tais formas estabelecem com a realidade constitutiva de seu presente.

\section{Referências bibliográficas}

ADORNO, T. W. (2003). "Posição do narrador no romance contemporâneo". In: . Notas de literatura I. Trad. Jorge M. B. de Almeida. São Paulo: Duas Cidades. p. 55-63.

AGAMBEN, G. (2004). O estado de exceção. Trad. Iraci D. Poleti. 2. ed. São Paulo: Boitempo.

AGUIAR E SILVA, V. M. (1991). “O texto literário”. In: Teoria da literatura. 8. ed. Coimbra: Livraria Almedina. p. 561-669. 
ARENDT, H. (1970). Sobre a violência. Trad. Maria Cláudia Drummond. s. 1. BAKHTIN, M. M. (1996). A cultura popular na Idade Média e no Renascimento. Trad. Yara Frateschi. São Paulo/Brasília: Hucitec/Editora da UnB.

BARTHES, R. (1972). Mitologias. Trad. Rita Buongermino e Pedro de Souza. São Paulo: Difusão Européia do Livro.

BENJAMIN, W. (1986a). "Sobre o conceito de história". In: Obras escolhidas 1: magia e técnica, arte e política. Trad. Sérgio Paulo Rouanet. 2. ed. São Paulo: Brasiliense. p. 222-32.

(1986b). “Crítica da violência, crítica do poder". In: de cultura, documentos de barbárie. São Paulo: Edusp/Cultrix. p. 160-75. (1985). "O narrador". In: Obras escolhidas 1: magia e técnica, arte e política. Trad. Sérgio Paulo Rouanet. 2. ed. São Paulo: Brasiliense. p. 197-221.

DÉBORD, G. (1997). A sociedade do espetáculo. Rio de Janeiro: Contraponto. DRUMMOND, R. (1996). A morte de D. J. em Paris. 8. ed. São Paulo: Ática. (1983). Quando fui morto em Cuba. 3. ed. São Paulo: Ática. (1981). Sangue de Coca-cola. São Paulo: Círculo do livro.

GUELFI, M. L. F. (2007). “O tempo do clichê e a estética do olhar na ficção contemporânea". Ipotesi. Juiz de Fora. v. 1, p. 119-31.

JANELA INDISCRETA (Rear Window) (1954). (Alfred Hitchcock, Estados Unidos).

METZ, C. (1972). A significação no cinema. São Paulo: Perspectiva. POUILLON, J. (1974). O tempo no romance. São Paulo: Edusp.

REISZ, K.; MILLAR, G. (1978). A técnica da montagem cinematográfica. Rio de Janeiro: Civilização Brasileira.

ROBBE-GRILLET, A. (1963). Por um novo romance. Lisboa: Europa-América. SANTIAGO, S. (1989). "O narrador pós-moderno". In: Nas malhas da letra. São Paulo: Cia. das Letras. p. 38-52.

TINIANOV, J. (2004). “La noción de construcción”. In: TODOROV, T. Teoría de la literatura de los formalistas rusos. Trad. Ana María Nethol. Buenos Aires: Siglo XXI. p. 85-8.

TOMACHEVSKI, B. (2004). “Temática”. In: TODOROV, T. Teoría de la literatura de los formalistas rusos. Trad. Ana María Nethol. Buenos Aires: Siglo XXI. p. 199-232.

XAVIER, I. (1988). “Cinema: revelação e engano”. In: AGUIAR, A. (Org.). O olhar. São Paulo: Cia das Letras. p. 367-384.

Recebido em agosto de 2011.

Aprovado em outubro de 2011. 


\section{resumolabstract}

Limites e intersecções do estético com o político no filme Janela indiscreta, de Alfred Hitchcock, e no conto "Sessão das quatro", de Roberto Drummond Wanderlan da Silva Alves

Analisamos o conto "Sessão das quatro", do escritor Roberto Drummond, e o filme Janela indiscreta (Rear Window), de Alfred Hitchcock, investigando como a linguagem de cada uma das narrativas representa, na sua forma, certos limites e intersecções do estético com o político. A partir de tensões individuais, as personagens dessas narrativas se veem inseridas em situações cotidianas em meio às quais as noções de público e privado se apresentam de modo difuso, a liberdade individual se encontra sitiada, e a violência (simbólica e de fato) emerge como elemento constitutivo de sua realidade. Sob tal condição, a criação de lugares enunciativos alternativos possibilita às personagens encontrar possíveis modos de agir criticamente num universo em que as leis e seus princípios éticos estão comprometidos por contextos de exceção.

Palavras-chave: Alfred Hitchcock, Roberto Drummond, literatura e cinema, narrativa e política

Borders and intersections between aesthetic and politic in the movie Rear Window, by Alfred Hitchcock, and the short-story "Sessão das quarto", by Roberto Drummond

Wanderlan da Silva Alves

We analyze the short-story "Sessão das quatro", by Brazilian writer Roberto Drummond, and the movie Rear Window, by Alfred Hitchcock. We discuss the language of narratives, focusing some points of borders and intersections between aesthetical and political elements in the construction and representation of forms of power. The characters of these narratives are inserted in the lands where the idea of public or private space is diffuse, the freedom is besieged, and the violence forms some structural elements of the reality. Then, the creation of alternative places for the enunciation gives to characters some possibilities for a critical action in that space where the concepts of law and ethic constitute the exception.

Key words: Alfred Hitchcock, Roberto Drummond, literature and movie; narrative and politic 